\title{
Comparative analysis of patients hospitalized for severe transaminase elevation according to etiology and laboratory findings
}

\section{Karaciğer enzim düzeylerinde ciddi yükseklik saptanan hastaların etiyoloji ve laboratuvar bulgularına göre karşılaştırmalı analizi}

\author{
Burak Bursalı $^{1 *}$ (D) Serhat Sayın ${ }^{2}$ (D), Ramazan Gökdemir ${ }^{1}$ (D) \\ ${ }^{1}$ Aksaray University, Aksaray Education and Research Hospital, Department of Internal Medicine, Aksaray, Turkey \\ * Corresponding author: Burak Bursalı E-mail: dr.burakbursali@hotmail.com ORCID: 0000-0002-4413-0232 \\ Received: 5 July 2018 Accepted: 16 September 2018
}

\begin{abstract}
Objective: The aim of this study is to investigate the etiological, epidemiological, clinical and laboratory findings of patients hospitalized in internal clinics with elevated transaminases and to create a point of view with clinical cues for acute hepatitis.

Methods: A total of 102 patients who were hospitalized in Internal Medicine and Infectious Diseases Clinics between January 2010 and September 2013 and whose transaminase levels were at least five times higher than the upper limit were included in the study. Patients' age, sex, etiology, laboratory findings, length of stay in the clinic, and duration of liver enzymes normalizations were examined retrospectively. ANOVA, Kruskal-Wallis and chi-square tests were used in the analysis of qualitative and quantitative data.
\end{abstract}

Results: Of the 102 patients with acute liver injury, 58 (56.9\%) were female and 44 (43.1\%) were male. The average age is 46 years. The study group consisted of three main groups: toxic hepatitis $(34.3 \%)$, acute viral hepatitis $(25.5 \%)$ and ischemic hepatitis (17.6\%). This was followed by acute nonbiliary pancreatitis $(6.9 \%)$, autoimmune hepatitis $(4.9 \%)$ and other $(10.8 \%)$ groups. Transaminase and bilirubin values were higher in acute viral hepatitis than other groups. Acute viral hepatitis group hospitalized for the longest time. The group which the liver enzymes recovered at the latest was toxic hepatitis. The two most common causes of toxic hepatitis were nonsteroidal anti-inflammatory drugs and herbal products. In the ischemic hepatitis group, the mean age was significantly higher. Alcohol use was not effective on the duration of hospitalization and normalization of liver enzymes.

Conclusion: Rapid determination of etiology, shortening hospitalization periot, and proper use of laboratory tests are important in patients with elevated transaminases. The purpose of this study is to enable the clinician to have an effective approach to acute liver damage.

Keywords: acute hepatitis, tranaminase elevation, liver cell damage 


\section{ÖZ}

Amaç: Transaminazlarda belirgin yükseklik saptanarak dahili kliniklere yatırılmış hastaların etiyolojik, epidemiyolojik, klinik ve laboratuar bulgularının değerlendirilerek akut hepatit tablosuna klinik ipuçları ile ışık tutmak amaçlanmıştır.

Gereç ve Yöntem: Ocak 2010-Eylül 2013 yılları arasında İç Hastalıkları ile Enfeksiyon Hastalıkları Kliniklerinde yatırılan, transaminaz düzeylerinde üst sınırın en az beş katı yükseklik saptanan 102 hasta çalışmaya dahil edildi. Hastaların yaş, cinsiyet, etiyoloji, laboratuvar bulguları, klinikte yatış süreleri ve karaciğer enzim düzeylerinin normal düzeye dönme süreleri retrospektif olarak incelendi. ANOVA, Kruskal-Wallis ve Ki-kare test niceliksel ve niteliksel verilerin analizinde kullanıldı.

Bulgular: Akut karaciğer hasarı olan 102 hastanın 58'i $(\% 56,9)$ kadın, 44'ü $(\% 43,1)$ erkekti. Yaş ortalaması 46 yıldı. Çalışmada 3 ana grubu toksik hepatit $(\% 34,3)$, akut viral hepatit $(\% 25,5)$ ve iskemik hepatit $(\% 17,6)$ grupları oluşturdu. Bunu akut nonbiliyer pankreatit $(\% 6,9)$, otoimmun hepatit $(\% 4,9)$ ve diğer $(\% 10,8)$ grupları izledi. Akut viral hepatitlilerde diğer gruplara kıyasla transaminaz ve bilirubin değerleri anlamlı $(p<0,05)$ olarak daha yüksekti. Hastanede en uzun süre yatırılan hasta grubunu akut viral hepatitliler oluşturdu. Karaciğer enzimlerinin en geç düzeldiği grubu toksik hepatitliler oluşturdu. Toksik hepatitlilerde en sık iki neden nonsteroid antiinflamatuvar ilaçlar ve bitkisel ürünlerdi. İskemik hepatit grubunda, yaş ortalaması tüm hepatit gruplarına göre anlamlı olarak yüksek saptandı. Alkol kullanımının, klinikte yatış süresi ve karaciğer enzimlerinin normalleşme süresi üzerinde etkili olmadığı görüldü.

Sonuç: Transaminaz yüksekliği olan hastalarda hızlıca etiyolojinin belirlenmesi, gereksiz yatış sürelerinin kısaltılması ve laboratuvar testlerinin yerinde ve akılcı kullanılması önemlidir. Çalışmamızın amacı akut karaciğer hasarına klinisyen gözüyle doğru ve etkin bir yaklaşım sağlayabilmektir.

Anahtar kelimeler: akut hepatit, transaminaz yüksekliği, karaciğer hücre hasarı

\section{INTRODUCTION}

Aminotransferases are sensitive indicators of liver cell damage and are most helpful in the identification of acute hepatocellular diseases such as hepatitis. The best way to increase the sensitivity and specificity of laboratory tests for the detection of liver diseases is to use a range of tests including Aminotransferases, Lactate Dehydrogenase (LDH), Alkaline Phosphatase (ALP), Bilirubin, Albumin and Prothrombin Time (PT). To reveal a diagnostic pattern, these tests may need to be repeated for days to weeks [1]. Aminotransferase elevation can usually be assessed at three different levels: elevation (more than 15 times the upper limit), moderate elevation (5-15 times the upper limit) and milder elevation (less than 5 times the upper limit) at severe levels [2]. Although not a limit and rule, practically aminotransferases have a preliminary pattern of viral hepatitis, toxic hepatitis, hepatitis due to medicine and ischemic liver damage more than $1000 \mathrm{U} / \mathrm{L}$ serum levels [1].

The approach to liver enzyme elevation should begin with history and physical examination. Family history (hemacromatosis, Wilson's disease, alpha-1 antitrypsin deficiency), use of herbal medicines, alcohol use, vitamins, medications for genetic diseases (eg endemic travel, intravenous drug use, homosexual relationship, tattooing, piercing), blood transfusion story and other accompanying diseases should be questioned. In the second step, the enzyme height should be determined to be cholestatic or hepatocellular. At the last stage, viral serologic markers, glucose, lipids, serum iron, total iron binding capacity and ferritin, hepatocellular ultrasonography (USG), blood seruloplasmin level, alpha-1 antitrypsin, autoimmune markers (antinuclear antibody, anti smooth muscle antibody and if necessary genetic screening tests should be requested [3].

\section{MATERIAL AND METHOD}

The epidemiological, clinical and laboratory results of 102 patients who were admitted with pre-diagnosis of acute liver injury in the clinics of Okmeydanı Training and Research Hospital between January 2010 and September 2013 and whose liver enzymes were more than five times the upper limit were retrospectively evaluated.

Patients who received previous chemotherapy and/or radiotherapy for malignancy, patients with chronic renal failure, chronic liver disease, acute exacerbations of chronic viral hepatitis and patients with multiorgan failure (such as hypovolemic, cardiogenic, septic shock) not included in the study. 
Table 1. Distribution of patients according to all parameters

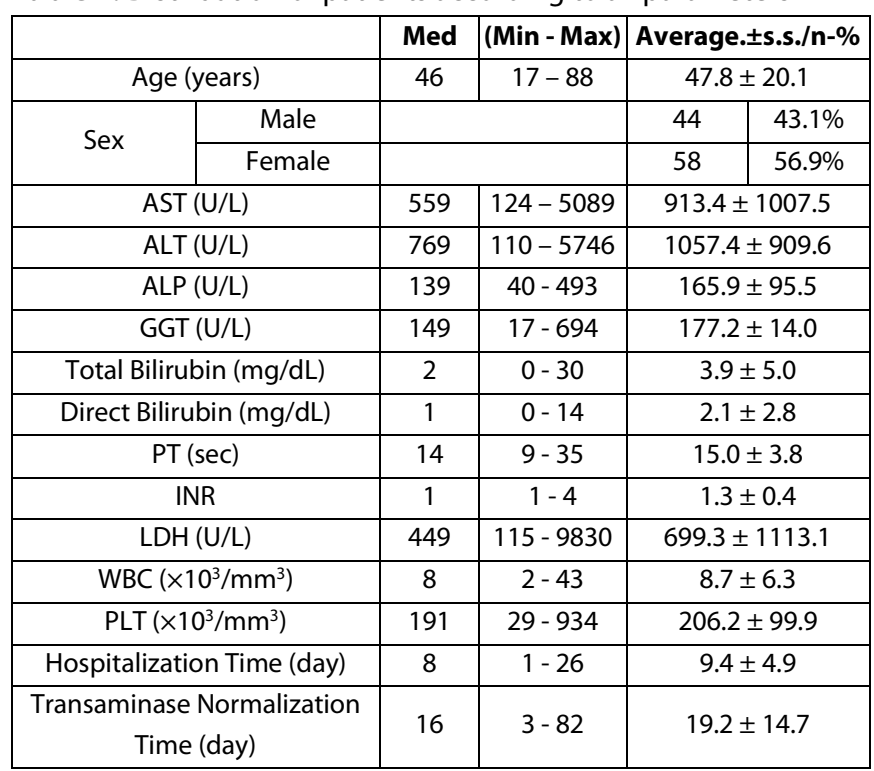

Table 2. Distribution of all patient groups according to etiology

\begin{tabular}{|l|c|c|}
\hline Hepatitis Etyology & $\mathbf{n}$ & $\%$ \\
\hline Acute Ischemic Hepatitis & 18 & 17.6 \\
\hline Toxic Hepatitis & 35 & 34.3 \\
\hline Mushroom & 3 & 2.9 \\
\hline NSAIDs & 16 & 15.7 \\
\hline Herbal Products & 13 & 12.7 \\
\hline Heroin/Cocaine & 3 & 2.9 \\
\hline Other & 6 & 5.9 \\
\hline Acute Viral Hepatitis & 26 & 25.5 \\
\hline Hepatitis B & 13 & 12.7 \\
\hline Hepatitis C & 3 & 2.9 \\
\hline Hepatitis A & 10 & 9.8 \\
\hline Autoimmune Hepatitis & 5 & 4.9 \\
\hline Acute Nonbilier Pancreatitis & 7 & 6.9 \\
\hline Others (Infections, Choledocholithiasis vs.) & 11 & 10.8 \\
\hline
\end{tabular}

The mean, standard deviation, median, min-max, ratio and frequency values were used in the descriptive statistics of the data. The statistical analysis was carried out using SPSS 22.0 (Statistical Package For Social Sciences 22). The distribution of the variables was checked by the Kolmogorov Simirnov test. ANOVA (Tukey test), Kruskal-Wallis (mannwhitney u test) and Chi-Square test were used to analyze the qualitative and quantitative data.

\section{RESULTS}

Of the 102 cases included in the study, 56.9\% $(n=58)$ were female and $43.1 \%(n=44)$ were male. The mean age of all patients was 46 (17-88). The study group consisted of three main groups: Toxic Hepatitis (34.3\%), Acute Viral Hepatitis (25.5\%) and Ischemic Hepatitis (17.6\%). This was followed by Acute Nonbiliary Pancreatitis (6.9\%) and Autoimmune Hepatitis (4.9\%). The remaining 11 (10.8\%) cases were evaluated as the Other group because of their different etiologic diagnoses (Table $\mathbf{1}$ and Table 2).

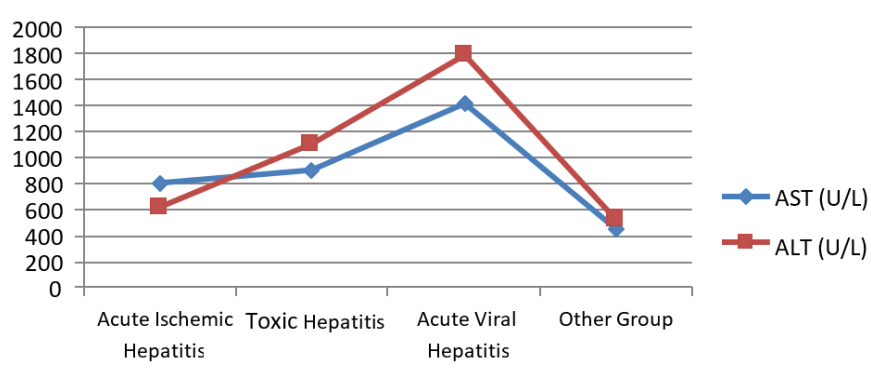

Figure 1. Distribution of ischemic, toxic, viral hepatitis and other groups according to mean AST and ALT values

Table 3. Toxic hepatitis subgroups by mean AST and ALT values

\begin{tabular}{|c|c|c|c|c|}
\hline & & AST (U/L) & ALT (U/L) & \\
\hline & & $\begin{array}{l}\text { AVE. } \\
\pm \text { S.S.S }\end{array}$ & $\begin{array}{l}\text { AVE. } \\
\pm \text { S.S.S }\end{array}$ & $\mathbf{p} / \mathbf{p}$ \\
\hline & MUSHROOM & $846 \pm 338$ & $976 \pm 536$ & \\
\hline & NSAIDs & $\begin{array}{l}869 \pm \\
1245\end{array}$ & $956 \pm 714$ & \\
\hline \multirow[t]{3}{*}{$\begin{array}{c}\text { TOXIC } \\
\text { HEPATITIS }\end{array}$} & HERBAL PRODUCTS & $797 \pm 434$ & $910 \pm 493$ & $\begin{array}{c}0.169 / \\
0.171\end{array}$ \\
\hline & HEROIN/COCAINE & $\begin{array}{c}1494 \pm \\
855\end{array}$ & $\begin{array}{c}2301 \pm \\
1247\end{array}$ & \\
\hline & OTHERS & $893 \pm 510$ & $\begin{array}{c}1218 \pm \\
411\end{array}$ & \\
\hline
\end{tabular}

The age of the patients in the acute ischemic hepatitis group (74.3 \pm 9.3$)$ was significantly $(p<0.05)$ higher than toxic hepatitis (40.9 \pm 15.2$)$, acute viral hepatitis $(36.5 \pm 14.0)$ and other hepatitis $(50.1 \pm 19.8)$ groups. Age of patients in acute viral hepatitis group was significantly lower than other hepatitis groups $(p<0.05)$.

The patients with viral hepatitis complained of jaundice and the elevations in bilirubin levels were more prevalent. Compared with other acute hepatitis groups, AST (mean=1411 U/L), ALT (mean=1783 U/L), total and direct bilirubin levels were significantly $(p<0.05)$ higher in the acute viral hepatitis group.

In the ischemic hepatitis group, aminotransferases exhibited a rapid rise and a rapid fall pattern that reached very high levels in the early period. In this group, the duration of liver enzymes to normal levels (days) was shorter $(p<0.05)$ as compared to the other groups (Table 4). There was no significant difference in ALP and GGT levels ( $p>0.05$ ) in all groups.

According to the etiology of toxic hepatitis, when we classified the subtypes, the most frequent use of nonsteroidal antiinflammatory drugs (NSAIDs), herbal products, fungi, heroin/cocaine were observed. There was no significant difference between these groups ( $p>0.05$ ) compared to AST and ALT values (Table 3). 
Table 4. Assessment of acute hepatitis groups according to hospitalization time (days) and hepatic enzymes normalization time (days)

\begin{tabular}{|c|c|c|c|c|c|}
\hline $\begin{array}{l}\text { Hepatitis } \\
\text { Type }\end{array}$ & \begin{tabular}{|c|} 
Acute \\
Ischemic \\
Ave. \pm s.s/n- \\
$\%$
\end{tabular} & \begin{tabular}{|c|} 
Toxic \\
Ave. \pm s.s/n- \\
$\%$
\end{tabular} & $\begin{array}{c}\text { Acute Viral } \\
\text { Ave. } \pm \text { s.s/n- } \\
\%\end{array}$ & $\begin{array}{c}\text { Other } \\
\text { Ave. } \pm \text { s.s/n- } \\
\%\end{array}$ & $\mathbf{p}$ \\
\hline $\begin{array}{c}\text { Hospitalization } \\
\text { Time (day) }\end{array}$ & $10.3 \pm 6.1$ & $8.7 \pm 4.3$ & $11.2 \pm 5.2$ & $7.7 \pm 3.7$ & 0.056 \\
\hline $\begin{array}{c}\text { Transaminase } \\
\text { Normalization } \\
\text { Time (day) }\end{array}$ & $7.4 \pm 2.9$ & $22.3 \pm 14.8^{*}$ & $22.1 \pm 9.6^{*}$ & $19.5 \pm 20.1^{*}$ & 0.004 \\
\hline
\end{tabular}

In acute ischemic hepatitis group, WBC value was significantly higher $(p<0.05)$ than toxic hepatitis, acute viral hepatitis and other groups. Mean LDH values of acute ischemic hepatitis and toxic hepatitis groups were respectively, $973 \mathrm{U} / \mathrm{L}$ and $804 \mathrm{U} / \mathrm{L}$, were higher than the other groups. However, there was no significant difference between the 4 groups in terms of LDH values ( $p>0.05$ ).

In the acute ischemic hepatitis group, the mean PT value was $18.6 \mathrm{sec}$, which was significantly higher than toxic hepatitis, acute viral hepatitis and other hepatitis group $(p<0.05)$. The mean duration of hospitalization was $8(9.4 \pm 4.9)$ days and the mean duration of hepatic enzymes was $16(19.2 \pm 14.7)$ days. There was no significant difference ( $p>0.05$ ) between the groups in terms of hospitalization time (days). In acute ischemic hepatitis group, liver enzymes normalization periot (days) was significantly shorter $(p<0.05)$ as compared to other groups (Table 4).

The use of alcohol was found not to be related to the time of liver enzymes reaching normal levels (days) and the length of hospitalization (days) ( $p>0.05)$.

\section{DISCUSSION}

Acute hepatitis; clinical appearence with hepatic inflammation and hepatic cell necrosis caused by viruses, drugs, alcohol, metabolic and autoimmune diseases, toxins. Clinic; may range from mild and self limiting acute hepatitis to hepatic cirrhosis, hepatocellular carcinoma and a much more severe and fatal hepatic failure [4].

NSAIDs, antibiotics, and antituberculosis drugs are the most common causes of acute liver injury [5]. Herbal and Dietary Supplements are increasingly used worldwide in recent years and constitute an important part of liver damage. The fact that people have more emphasis on their appearance in recent times has increased the tendency for such food supplements. In a study conducted, it was seen that the most common causes of liver damage were nutrient supplements used to improve the body and lose weight [6].
In this study, NSAIDs and herbal products were observed as the most common factors with 35 cases as $34.3 \%$ of the largest group of toxic hepatitis. At the same time toxic hepatitis was the group in which the transaminases recovered at the latest (mean $=22.3 \pm 14.8$ days). In this group, 13 toxic hepatitis cases were learned to drink herbal teas to lose weight. Careful attention should be paid to the use of these reinforcements, whose contents and hiding conditions are not well known.

Symptoms and signs are very variable in the acute phase of hepatitis. Various conditions ranging from asymptomatic transaminase elevations to acute liver failure can be seen. For this reason, difficulties can be experienced. Acute hepatitis may rarely complicate with severe hepatic failure after rapid deterioration of transaminases due to etiology, patient age and developmental rate of hepatic encephalopathy [7]. In our study, fulminant and/or subfulminant hepatic failure was not detected in patients. This is because the patients who are thought to have progressed to the hepatic insufficiency are transferred to the intensive care and gastroenterology clinics, and follow-up and treatment are carried out in these units.

In cases of acute viral hepatitis, aminotransferase levels usually rise to the highest level before jaundice develops and then begin to fall. There is a significant increase in bilirubin levels [8]. Jaundice is seen in average $70 \%$ in acute hepatitis A, 33-50\% in acute hepatitis B and $20-33 \%$ in acute hepatitis $C$ [9]. Serum LDH concentration is typically found at about $50 \%$ of cases, slightly above the reference limit level $[10,11]$. In our study, acute viral hepatitis group was the second most common group with $27.3 \%$. Among the viral hepatitis subgroups, $B$ hepatitis was the most common group with $12.7 \%$, A hepatitis with $9.8 \%$ and $C$ hepatitis with $2.3 \%$. AST (ave $=1411 \mathrm{U} / \mathrm{L}$ ) and $\mathrm{ALT}$ (ave $=1783 \mathrm{U} / \mathrm{L}$ ) and total and direct bilirubin values were significantly higher in the acute viral hepatitis group than the other groups $(p<0.05)$. Eight of the 13 patients with acute viral hepatitis $B$ and 10 patients with acute viral hepatitis A complained of jaundice at the time of admission to the emergency department. At the same time, patients with acute viral hepatitis constituted the group with the longest duration of hospitalization $(11.2 \pm 5.2)$, but there was no significant difference between the groups in terms of hospitalization time.

Ischemic hepatitis is an important and mortal disease that developes due to underlying cardiac, pulmonary and vascular diseases. Pathogenesis is liver hypoperfusion and ischemia. The AST/ALT ratio is often high, especially in the liver zone 3 , where AST is detected at a higher rate. 
Transaminases rise quickly and normalize within 7-10 days as clinical improvement [12]. The etiologies of 18 patients with acute ischemic hepatitis in our study were chronic ischemic heart disease, heart failure, chronic obstructive pulmonary disease, severe acute bleeding and sepsis. The duration of hospitalization is prolonged because these cases are generally elderly and accompanying chronic diseases. The mean duration of hospitalization in the acute ischemic hepatitis group was $10.3 \pm 6.1$ days in our study. The reason for this relatively shorter duration is the referral of five patients to intensive care units due to acute hepatic failure in the early period.

In ischemic damage, transaminase levels decline rapidly after peaking. However, this has no value on prognosis. Because both the resolution period and the widespread liver necrosis period can cause this clinic. In this case, elevations in PT and serum bilirubin levels are more warning on hepatic insufficiency. Another finding is that LDH, as an important biyochemical test on ischemic hepatitis, can reach high levels [13]. In our study, acute ischemic hepatitis cases constituted the highest LDH levels. At the same time, PT, which is considered as the most important prognostic indicator in liver damage in the early period, was significantly higher $(p<0.05)$ than other hepatitis groups in acute ischemic hepatitis. In our study, five patients with acute ischemic hepatitis were rapidly transferred to intensive care units after worsening of general condition, prolonged PT values and severe liver injury.

Acute pancreatitis is characterized by the presence of clinically abrupt abdominal pain and elevation of pancreatic digestive enzymes in the serum and/or urine and the presence of radiological changes in the pancreas [14]. Acute nonbilier pancreatitis was diagnosed in seven patients come up with abdominal pain, loss of appetite, nausea and vomiting. Amylase and lipase levels were high. These patients constituted $6.9 \%$ of the study group. Only 4 of these patients have had chronic alcohol use. Serum LDH levels, which were prognostic value in acute pancreatitis at first admission, were similar to ischemic hepatitis (ave $=380.4 \pm 116 \mathrm{U} / \mathrm{L}$ ).

\section{CONCLUSIONS}

A significant amount of time is spent to determine the etiology of acute hepatitis in clinics. It is very important to identify diagnosis and start treatment on early way and decide whether intensive care unit and/or liver transplantation is needed on quickly. Retrospective studies on this topic have not been evaluated in a general perspective and only subgroups such as acute viral hepatitis, toxic hepatitis or acute pancreatitis have been discussed. For this reason, an important goal of our study is to constitude a correct approach to all aspects of acute liver injury for clinicians.

\section{DECLARATION OF CONFLICT OF INTEREST}

The authors disclosed no conflict of interest during the preparation or publication of this manuscript.

\section{REFERENCES}

1. Kasper D, Fauci A, Hauser S, Longo D, Jameson J, Loscalzo J. Harrison's Principles of Internal Medicine; 2015. (doi: 0.1036/007149619X).

2. Green RM, Flamm S. AGA technical review on the evaluation of liver chemistry tests. Gastroenterology 2002; 123: 1367-84. (doi: 10.1053/gast.2002.36061).

3. Giannini EG, Testa R, Savarino V. Liver enzyme alteration: A guide for clinicians. CMAJ. 2005; 172: 367-79. (doi: 10.1503/cmaj.1040752).

4. Patel S. Hepatitis. SA Pharm J 2015; 82: 20-3.

5. Alempijevic T, Dragasevic $S$, Zec $S$, Popovic D, Milosavljevic T. Non-alcoholic fatty pancreas disease. Postgrad Med J 2017; 93: 226-30. (doi: 10.1136/postgradmedj-2016-134546).

6. Navarro VJ, Khan I, Björnsson E, Seeff LB, Serrano J, Hoofnagle $\mathrm{JH}$. Liver injury from herbal and dietary supplements. Hepatology 2017; 65: 363-73. (doi: 10.1002/hep.28813).

7. Bernal W, Wendon J. Acute Liver Failure. N Engl J Med 2013; 369: 2525-34. (doi: 10.1056/NEJMra1208937).

8. Clermont RJ, Chalmers TC. The transaminase tests in liver disease. Med (United States) 1967; 46: 197-207. (doi: 10.1097/00005792-196703000-00012).

9. Dufour DR, Lott JA, Nolte FS, Gretch DR, Koff RS, Seeff LB. Diagnosis and monitoring of hepatic injury. II. Recommendations for use of laboratory tests in screening, diagnosis, and monitoring. Clin Chem 2000; 46: 2050-68. (doi: 10.1016/j.ejmech.2005.12.002).

10. Seeto RK, Fenn B, Rockey DC. Ischemic hepatitis: Clinical presentation and pathogenesis. Am J Med 2000; 109: 109-13. (doi: 10.1016/S0002-9343(00)00461-7). 
11. Singer AJ, Carracio TR, Mofenson HC. The temporal profile of Increased transaminase levels in patients with acetaminophen-ınduced liver dysfunction. Ann Emerg Med 1995; 26: 49-53. (doi: 10.1016/S01960644(95)70237-7).

12. Lightsey JM, Rockey DC. Current concepts in ischemic hepatitis. Curr Opin Gastroenterol. 2017; 33: 158-63. (doi: 10.1097/MOG.0000000000000355).
13. Cassidy WM, Reynolds TB. Serum lactic dehydrogenase in the differential diagnosis of acute hepatocellular injury. $J$ Clin Gastroenterol 1994; 19: 118-21. (doi: 10.1097/00004836-199409000-00008).

14. Mayumi T, Takada T, Kawarada Y, et al. Management strategy for acute pancreatitis in the JPN Guidelines. J Hepatobiliary Pancreat Surg 2006; 13: 61-7. (doi: 10.1007/s00534-005-1053-5). 